\title{
Association between 28 single nucleotide polymorphisms and type 2 diabetes mellitus in the Kazakh population: $a$ case-control study
}

\author{
Nurgul Sikhayeva ${ }^{1,2^{*}}$ D, Aisha Iskakova ${ }^{1}$, Nuria Saigi-Morgui ${ }^{3}$, Elena Zholdybaeva ${ }^{1}$, Chin-Bin Eap ${ }^{3,4}$ \\ and Erlan Ramanculov ${ }^{5,1,2}$
}

\begin{abstract}
Background: We evaluated the associations between single nucleotide polymorphisms and different clinical parameters related to type 2 diabetes mellitus (T2DM), obesity risk, and metabolic syndrome (MS) in a Kazakh cohort.

Methods: A total of 1336 subjects, including 408 T2DM patients and 928 control subjects, were recruited from an outpatient clinic and genotyped for 32 polymorphisms previously associated with T2DM and obesity-related phenotypes in other ethnic groups. For association studies, the chi-squared test or Fisher's exact test for binomial variables were used. Logistic regression was conducted to explore associations between the studied SNPs and the risk of developing T2DM, obesity, and MS, after adjustments for age and sex.

Results: After excluding four SNPs due to Hardy-Weinberg disequilibrium, significant associations in age-matched cohorts were found betweenT2DM and the following SNPs: rs9939609 (FTO), rs13266634 (SLC30A8), rs7961581 (TSPAN8/LGR5), and rs1799883 (FABP2). In addition, examination of general unmatched T2DM and control cohorts revealed significant associations between T2DM and SNPsrs1799883 (FABP2) and rs9939609 (FTO). Furthermore, polymorphisms in the FTO gene were associated with increased obesity risk, whereas polymorphisms in the FTO and FABP2 genes were also associated with the risk of developing MS in general unmatched cohorts.

Conclusion: We confirmed associations between polymorphisms within the SLC30A8, TSPAN8/LGR5, FABP2, and FTO genes and susceptibility to T2DM in a Kazakh cohort, and revealed significant associations with anthropometric and metabolic traits. In particular, FTO and FABP2 gene polymorphisms were significantly associated with susceptibility to MS and obesity in this cohort.
\end{abstract}

Keywords: Genetic variants, Kazakh cohort, Metabolic syndrome, Obesity, Type 2 diabetes mellitus

\section{Background}

Type 2 diabetes mellitus (T2DM) is the most widespread endocrine disease and one of the most acute medical and societal problems, as it leads to early disability and increased mortality from different complications $[1,2]$. More than 170 million people currently suffer from T2DM [3]. According to the Kazakhstan Diabetes Association, by

\footnotetext{
* Correspondence: ksnurgul@gmail.com

${ }^{1}$ National Center for Biotechnology, 13/5 Korgalzhyn str, Astana 010000, Kazakhstan

${ }^{2}$ L.N. Gumilyov Eurasian National University, Astana, Kazakhstan

Full list of author information is available at the end of the article
}

the end of 2013, more than 273,000 individuals were identified as having type 1 or type 2 diabetes; this accounts for $1.6 \%$ of the country's population. Moreover, T2DM is the predominant form of diabetes in Kazakhstan, as it was detected in $93 \%$ of diabetes patients [4].

T2DMis a multifactorial disease; its pathogenesis is characterised by $\beta$-cell dysfunction accompanied by reduced insulin secretion and $\beta$-cell mass, increased glucagon secretion, a diminished incretin response, augmented liver glucose production, enhanced glucose reabsorption, activated lipolysis, reduced glucose absorption by the muscles, and neurotransmitter dysfunctions [5, 6]. Many 
studies have revealed connections between T2DM and obesity and metabolic syndrome (MS). Genetic variation and environmental factors are thought to contribute to the development of T2DM. The greatest progress in the identification of genetic factors underlying T2DM has been achieved using genome-wide association studies (GWAS) in different populations [6]. However, positive associations need to be evaluated in other ethnic populations, due to associated differences in the frequencies of genetic variants, and also because of differences in the contribution of environmental factors [6-10].

More than 100 genetic variants are currently thought to be associated with the risk of developing T2DM. The majority of these genes affect insulin secretion $[6,11,12]$, although the exact molecular mechanisms through which this occurs remain largely unknown. The present study aimed to determine whether 32 genetic polymorphisms, previously identified by GWAS and candidate gene studies using other ethnic populations, are associated with susceptibility to T2DMand obesity-related phenotypes in a Kazakh cohort. Different clinical metabolic phenotypes related to T2DM, such as body mass index (BMI), blood pressure, waist to hip circumference, plasma levels of glucose, cholesterol, triglycerides (TGs), low-density lipoproteins (LDL), high-density lipoproteins (HDL), C-peptide, and glycosylated haemoglobin (HbA1c) were also examined.

\section{Methods}

\section{Subjects and clinical tests}

Samples were collected from one region of Kazakhstan (Almaty). The study participants included only ethnic Kazakhs, according to self-reported information; participants who self-identified as being of Russian, Western European, East Asian, or Middle Eastern origin were excluded. Blood samples were obtained from 408 T2DM patients recruited from the outpatient clinic of the Asfendiyarov Kazakh National Medical University (Almaty, Kazakhstan). T2DM was diagnosed according to the World Health Organization (WHO) criteria, specifically, fasting plasma glucose $\geq 7.0 \mathrm{mmol} / \mathrm{L}$, and/or HbA1c test $\geq 6.5 \%$,and/or postprandial plasma glucose test $\geq 11.1 \mathrm{mmol} / \mathrm{L}$, and/or the prescription of antidiabetic medications $[13,14]$. Nine hundred and twentyeight control subjects were included after receiving an annual health check-up conducted at the Asfendiyarov Kazakh National Medical University. Individuals from the control group were unrelated, randomly selected, and had not been diagnosed with T2DM.In the control group, there were several participants with elevated levels of glucose and HbA1c. These individuals had not been diagnosed with diabetes before sampling or during health check-up, at which time blood samples were collected from these participants. Therefore, we did not exclude these samples from the control group. Participants with acute diseases and women who were pregnant were also excluded from the control group.

Overweight and obesity were defined according to the WHO criteria as follow: normal weight, $18.5 \mathrm{~kg} / \mathrm{m}^{2} \leq$ body mass index (BMI) $<25 \mathrm{~kg} / \mathrm{m}^{2}$; overweight, $25 \mathrm{~kg} /$ $\mathrm{m}^{2} \leq \mathrm{BMI} \leq 30 \mathrm{~kg} / \mathrm{m}^{2} ;$ obesity, BMI $>30 \mathrm{~kg} / \mathrm{m}^{2}$. The presence of at least three of the following components defined MS (ATPIII criteria): central obesity (waist circumference (WC) $>88 \mathrm{~cm}$ in women, $>102 \mathrm{~cm}$ in men), hypertriglyceridemia (TGs $\geq 1.6 \mathrm{mmol} / \mathrm{L}$ ), HDL cholesterol $<1.3 \mathrm{mmol} / \mathrm{L}$, hypertension (systolic blood pressure (SBP) $\geq 130 \mathrm{mmHg}$ or diastolic blood pressure (DBP) $\geq 85 \mathrm{mmHg}$ ), fasting plasma glucose $\geq 5.5 \mathrm{mmol} / \mathrm{L}$, or drug treatment for elevated blood glucose [15].

Anthropometric indices including weight, height, WC, and blood pressure were measured following standard protocols. Height and weight were measured with the participants wearing light clothes and without shoes. WC was measured at the midpoint between the iliac crest and lowest rib. Hip circumference $(\mathrm{HC})$ was measured to the nearest centimetre at the greatest protrusion of the buttocks, just below the iliac crest. Blood pressure was measured in a sitting position with a mercury sphygmomanometer. BMI was calculated as the individual's body weight in kilograms divided by the square of his/her height in meters. Waist to hip ratio was calculated as WC in centimetres divided by the $\mathrm{HC}$ in centimetres. Biochemical variables including fasting blood glucose, TGs, cholesterol, HDL, LDL, and HbA1c, were measured using blood samples collected after overnight fasting with biochemical auto-analysers (BioChem Analette, HTI, Walpole, MA, USA and Cobas c 111, Roche Diagnostics Ltd., Rotcreuz, Switzerland). Fasting insulin and C-peptide (used only for classification of diabetes and not measured in the control group) were determined using automated enzyme immunoassays and a ChemWell 2910 chemistry analyser (Awareness Technologies, Palm City, FL, USA).

Written informed consent was obtained from all participants and the protocol was approved by the Ethics Committee of National Centre for Biotechnology, Astana, Kazakhstan (No. 10.14.03.2012).

\section{SNP selection and genotyping}

We selected 32 genetic polymorphisms previously associated with T2DM and obesity-related phenotypes for investigation in this study (Table 1). DNA was extracted using the salting-out method [16]. SNPs were detected using the TaqManOpenArray Real-Time PCR Platform (LifeTechnologies, Foster City, CA, USA). Analyses were conducted according to the manufacturer's standard protocols and genotype calls were made by OpenArray SNP Genotyping Analysis Software, version 1.0.3. 
Table 1 Characteristic of selected SNPS

\begin{tabular}{|c|c|c|c|c|c|c|}
\hline SNP ID & $\begin{array}{l}\text { Gene or nearby } \\
\text { region }\end{array}$ & Location & Position & Traits & OR $[95 \% \mathrm{Cl}]$ & References \\
\hline rs3751812 & FTO & $16 q 12.2$ & Intron 1 & Obesity & $1.42[1.33-1.52]$ & Frayling et al., 2007 [60] \\
\hline rs8050136 & FTO & $16 q 12.2$ & Intron 1 & T2DM; obesity & $\begin{array}{l}1.22[1.07-1.40] 1.45 \\
{[1.09-1.93]}\end{array}$ & Liu et al., 2010 [26] \\
\hline rs9939609 & FTO & $16 q 12.2$ & Intron 1 & T2DM; obesity & $\begin{array}{l}1.19[1.04-1.37] ; 1.39 \\
{[1.04-1.85]}\end{array}$ & Liu et al., 2010 [26] \\
\hline rs10811661 & CDKN2AVB & $9 p 21.3$ & Intergenic & T2DM & $1.20[1.14-1.25]$ & Zeggini et al., 2007 [27] \\
\hline rs2383208 & CDKN2A $B$ & $9 p 21.3$ & Intergenic & T2DM & $1.34[1.27-1.41]$ & Takeuchi et al., 2009 [28] \\
\hline rs1111875 & HHEX & $10 q 23.33$ & 3'-UTR & T2DM & $1.21[1.15-1.28]$ & Takeuchi et al., 2009 [28] \\
\hline rs5015480 & HHEX & $10 q 23.33$ & Intergenic & T2DM & $1.17[1.11-1.24]$ & Zegginietal., 2008 \\
\hline rs13266634 & SLC30A8 & $8 q 24.11$ & Exon 8, missense & T2DM & $1.16[1.10-1.22]$ & $\begin{array}{l}\text { Rung et al., } 2009 \text { [29], } \\
\text { Takeuchi et al., } 2009 \text { [28] }\end{array}$ \\
\hline rs4506565 & TCF7L2 & $10 q 25.3$ & Intron 3 & T2DM & $1.36[1.20-1.54]$ & $\begin{array}{l}\text { Wellcome Trust Case Control } \\
\text { Consortium (2007) [30] }\end{array}$ \\
\hline rs7903146 & TCF7L2 & $10 q 25.3$ & Intron 4 & T2DM & 1.49 [1.39-1.59] & Timpson et al., 2009 [31] \\
\hline rs4402960 & IGF2BP2 & $3 q 27.2$ & Intron 2 & T2DM & $1.14[1.08-1.21]$ & Takeuchi et al., 2009 [28] \\
\hline rs5215 & KCNJ11 & $11 p 15.1$ & Exon 1 & T2DM & $1.16[1.09-1.23]$ & Zeggini et al., 2008 [12] \\
\hline rs7756992 & CDKAL1 & $6 p 22.3$ & Intron 5 & T2DM & $1.20[1.13-1.27]$ & Steinthorsdottir et al., 2007 [32] \\
\hline rs4712523 & CDKAL1 & $6 p 22.3$ & Intron 5 & T2DM & $1.27[1.21-1.33]$ & Takeuchi et al., 2009 [28] \\
\hline rs9465871 & CDKAL 1 & $6 p 22.3$ & Intron 5 & T2DM & $1.18[1.04-1.34]$ & $\begin{array}{l}\text { Wellcome Trust Case Control } \\
\text { Consortium (2007) [30] }\end{array}$ \\
\hline rs7961581 & nearTSPAN8/LGR5 & $12 q 21.1$ & Intergenic & T2DM & 1.09 [1.06-1.12] & Zeggini et al., 2008 [12] \\
\hline rs864745 & $J A Z F 1$ & 7p15.2-p15.1 & Intron 1 & T2DM & $1.10[1.07-1.13]$ & Zeggini et al., 2008 [12] \\
\hline rs12779790 & nearCDC123/CAMK1D & 10p13 & Intergenic & T2DM & $1.11[1.07-1.14]$ & Zeggini et al., 2008 [12] \\
\hline rs10490072 & $B C L 11 A$ & $2 p 16.1$ & 3' ofgene & T2DM & $1.05[1.03-1.08]$ & Zeggini et al., 2008 [12] \\
\hline rs10923931 & NOTCH2 & 1p13-p11 & Intron 5 & T2DM & $1.13[1.08-1.17]$ & Zeggini et al., 2008 [12] \\
\hline rs7578597 & THADA & $2 p 21$ & Exon 24, missense & T2DM & $1.15[1.10-1.20]$ & Zeggini et al., 2008 [12] \\
\hline rs2025804 & $L E P R$ & $1 \mathrm{p} 31$ & Intron 2 & BMl & & Traurig et al., 2012 [33] \\
\hline rs2641348 & ADAM30 & $1 \mathrm{p} 12$ & Exon 1, missense & T2DM & $1.10[1.06-1.15]$ & Zeggini et al., 2008 [12] \\
\hline rs9472138 & near VEGFA & $6 p 21.1$ & Intergenic & T2DM & 1.06 [1.04-1.09] & Zeggini et al., 2008 [12] \\
\hline rs1042714 & ADRB2 & $5 q 31-q 32$ & Exon 1, missense & T2DM & $0.56[0.36-0.91]$ & Pinelli et al., 2006 [34] \\
\hline rs4994 & ADRB3 & $8 p 12$ & Exon 1, missense & T2DM & $1.27[1.07-1.51]$ & Jing et al., 2012 [35] \\
\hline rs1799883 & $F A B P 2$ & $4 q 28-q 31$ & Exon 2, missense & $\mathrm{T} 2 \mathrm{DM}$ & $1.29[1.08-1.49]$ & Qiu et al., 2014 [8] \\
\hline rs1801282 & PPARG & $3 p 25$ & Exon 4, missense & $\mathrm{T} 2 \mathrm{DM}$ & 1.14 [1.08-1.20] & Scott et al., 2007 [11] \\
\hline rs8192678 & PPARGC1A & $4 p 15.1$ & Exon 8, missense & T2DM & 1.07 [1.00-1.15] & Barroso et al., 2006 [37] \\
\hline rs780094 & GCKR & $2 p 23$ & Intron 16 & $\mathrm{~T} 2 \mathrm{DM}$ & $0.71[0.58-0.85]$ & Onuma et al., 2010 [38] \\
\hline rs7944584 & MADD & $11 p 11.2$ & Intron 25 & T2DM & 1.63 [1.32-2.02] & Hu et al., 2010 [39] \\
\hline rs1153188 & DCD-VDAC1P5 & $12 q 13$ & Intergenic & T2DM & $1.08[1.05-1.11]$ & Zeggini et al., 2008 [12] \\
\hline
\end{tabular}

Data analyses were performed using TaqManGenotyper Software V1.3.

\section{Statistical analysis}

Quantitative data are presented as median and range unless otherwise mentioned, whereas qualitative data are presented as percentages. Statistical analysis was performed using R software (version 3.1.2, Foundation for Statistical Computing, Vienna, Austria) and Arlequin software (version 3.1.2, University of Bern, Bern, Switzerland) [17-19]. The conformance of genotype frequency distributions to the Hardy-Weinberg equilibrium (HWE) was assessed using the $\mathrm{X}^{2}$ criterion $(\alpha=0.05, \mathrm{df}=2)$. For association studies, the chi-square test or Fisher's exact test for binomial variables was used. Logistic regression was conducted to determine the association between the studied SNPs and the risk of T2DM, obesity and MS, after adjustments for age and 
sex. Odds Ratios (ORs) were calculated and presented with $95 \%$ confidence interval $(\mathrm{CI})$ values. For quantitative non-parametric data, the Wilcoxon signed rank sum test was used to compare variables between two groups and the Kruskal-Wallis test was used when variables were compared between three groups. Differences were considered statistically significant if $P<0.05$. For genetic analysis, the additive model was used. Power analysis (with $\beta=0.20$ and $\alpha=0.05$ ) was performed using Power and Sample Size Calculation software (version 3.1.2, Vanderbilt University, Nashville, Tennessee, USA) designed by W.D. Dupont and W.D. Plummer [20]. Data from the HapMap database were used for the comparative analysis of differences in genotype and haplotype frequencies among Kazakh and world populations (HapMap Genome Browser release \#27 [Phases 1-3: merged genotypes and frequencies]) [21]. The exact test of the population differentiation (Markov chain) method was used for analysis. The burn-in period of 10,000 dememorisation steps wasfollowed by 100,000 Markov-Chain steps [22].

\section{Results}

\section{General T2DM and control cohorts}

Baseline clinical characteristics of the 1336 subjects (928 control subjects and 408 individuals withT2DM) are listed in Table 2. There were 257 males and 671 females in the control group (median age 32 [range, 18-61] years, median BMI 23.0 [range, 15.1-54.0] $\mathrm{kg} / \mathrm{m}^{2}$, median fasting plasma glucose 4.9 [range, 3.2-7.8] $\mathrm{mmol} / \mathrm{L}$ ). The T2DM group consisted of 182 males and 226 females (median age 59 [range, 29-84] years, median BMI 29.3 [range, $18.2-47.6] \mathrm{kg} / \mathrm{m}^{2}$, median fasting plasma glucose 9.6 [range, 3.6-30.5] mmol/L). With the exception of height, all measured parameters significantly differed between the patients and control subjects.

\section{Age-matched T2DM and control cohorts}

T2DM usually develops in middle-aged and older individuals. Because the control group consisted of subjects younger than those in T2DM group, to avoid bias (i.e. the inclusion of young controls with genetic risk factors for developingT2DM), a subset of control subjects was agematched to diabetic subjects $(n=141$ controls, and $n=223$ cases) as closely as possible, with a median age of 52 years in control group and 53 years in the T2DM group.

The clinical and biochemical characteristics of agematched study subjects are listed in Table 3. The median weight of age-matched T2DM group subjects (82 [range, 46-135] kg) was higher than that of age-matched control individuals. In the T2DM group, values for BMI, SBP, DBP, WC, fasting plasma glucose, and TGs were higher, whereas HDL levels were lower than those in the age-matched control group. In contrast, height, total cholesterol, and LDL levels, as well as the proportion of male subjects were similar between the two agematched groups.

Table 2 Clinical and biochemical characteristics of the general study cohorts

\begin{tabular}{|c|c|c|c|}
\hline & Control subjects & Type 2 diabetic patients & $P$-value \\
\hline $\mathrm{N}$ & 928 & 408 & \\
\hline Male,\% (n) & $27.7 \%(257)$ & $44.6 \%(182)$ & $<10^{-5}$ \\
\hline Age, years & $32(18-61)$ & $59(29-84)$ & $<10^{-5}$ \\
\hline Weight, kg & $63(40-147)$ & $80(46-135)$ & $<10^{-5}$ \\
\hline Height, cm & $165(140-197)$ & $165(148-188)$ & 0.154 \\
\hline $\mathrm{BMI}, \mathrm{kg} / \mathrm{m}^{2}$ & $23.0(15.1-54.0)$ & $29.3(18.2-47.6)$ & $<10^{-5}$ \\
\hline Systolic blood pressure, mm Hg & $110(60-150)$ & $130(100-220)$ & $<10^{-5}$ \\
\hline Diastolic blood pressure, $\mathrm{mm} \mathrm{Hg}$ & $70(50-100)$ & $80(60-130)$ & $<10^{-5}$ \\
\hline Waist circumference, $\mathrm{cm}$ & $80(48-180)$ & $94(60-160)$ & $<10^{-5}$ \\
\hline Hip circumference, cm & - & $100(62-165)$ & - \\
\hline Waist/hip ratio & - & $0.95(0.54-1.83)$ & - \\
\hline Glucose, mmol/L & $4.9(3.2-7.8)$ & $9.6(3.6-30.5)$ & $<10^{-5}$ \\
\hline Cholesterol, mmol/L & $4.2(2.0-11.8)$ & $5.2(2.1-16.7)$ & $<10^{-5}$ \\
\hline Triglycerides, mmol/L & $1.0(0.2-6.5)$ & $1.8(0.2-17.6)$ & $<10^{-5}$ \\
\hline Low-density lipoproteins, mmol/L & $3.88(1.05-15.5)$ & $4.775(0.23-8.67)$ & $<10^{-5}$ \\
\hline High-density lipoproteins, mmol/L & $1.32(0.59-2.8)$ & $1.27(0.6-3.6)$ & 0.001 \\
\hline $\mathrm{HbA1c}, \%$ & $5.4(4.0-7.3)$ & $7.6(4.4-16.4)$ & $<10^{-5}$ \\
\hline Insulin, $\mu \mathrm{IU} / \mathrm{mL}$ & - & $12.10(0.02-97.0)$ & - \\
\hline C-peptide, ng/mL & - & $4.20(0.08-36.30)$ & - \\
\hline
\end{tabular}

Data are expressed as median (range) unless otherwise specified 
Genetic analysis ofT2DM markersin the age-matched and general T2DM and control cohorts

We genotyped 32 common SNPs (representing 25 genes/loci), of which28 were in HWE (Additional file 1). Four polymorphisms that did not conform to HWE criteria were excluded from subsequent analyses. In the age-matched T2DM and control Kazakh cohorts, logistic regression analysis after adjustments for age and gender revealed four SNPs within four distinct loci that were significantly associated with T2DM as follows: rs9939609 (FTO), OR $=1.52$, CI $[1.03-2.26]$, $P=0.04$; rs13266634(SLC30A8), OR $=0.68$, CI $[0.49-$ 0.93], $P=0.02$; rs7961581(TSPAN8/LGR5), $\mathrm{OR}=1.54$, CI [1.05-2.27], $P=0.03$; rs1799883(FABP2), OR $=1.51$, CI [1.06-2.13], $P=0.02$ ) (Table 4). In addition, two additional SNPs within the FTO gene, rs3751812 and rs8050136, tended to be associated with T2DM $(P<0.1)$. Subsequently, these associations were also tested in general T2DM and control cohorts (Additional file 2, $n=1336$ ) and significant associations were found betweenT2DM and rs1799883 (FABP2), rs3751812 (FTO), rs8050136 (FTO), and rs9939609 (FTO), with statistical power values of $75 \%, 90 \%, 88 \%$, and $95 \%$, respectively.

\section{Genetic analysis of BMI, obesity, and other metabolic} parameters in the general unmatched control cohort Associations between BMI and SNPs that were found to be associated with T2DM (as previously mentioned) were tested in the general control group (Additional file 3). Data from several individuals were excluded from analyses because of missing parameters and genotype data. Thus, for FTO rs3751812 $(P=0.046)$ and FTO rs8050136 $(P=0.03)$, the highest $\mathrm{BMI}$ values were identified in TT and AA genotype-carriers, respectively. SBP was higher $(P=0.046)$ and HDL levels were lower $(P=0.02)$ for $F A B P 2$ rs1799883 TT genotypes (Additional files 4 and 5) compared to those parameters in non-carriers. Polymorphisms within the FTO gene were also associated with LDL levels (rs3751812: $P=0.04$; rs8050136: $P=0.03$; rs9939609: $P=0.02$ ) (Additional file 6) and cholesterol levels (rs9939609: $P=0.04$ ) (Additional file 7). However, no associations with TG and HbA1c levels were found for any of the six studied SNPs (data not shown).

Several studies have shown that obesity is likely to be a major risk factor for T2DM onset. Therefore, we tested the association between all 28 SNPs and obesity status (Additional file 8). After adjustments for age and gender, and considering only extreme BMI values (i.e. $<25$ and $>30$ ), only FTO polymorphisms were associated with obesity risk ( $\mathrm{rs} 3751812$ : $\mathrm{OR}=1.51, \mathrm{CI}$ [1.14-1.99], $P=0.003$, power $=72 \%$; rs850136: $\mathrm{OR}=1.52$, CI $[1.15-2.01], P=0.003$, power $=74 \%$; rs9939609: $\mathrm{OR}=1.44, \mathrm{CI}[1.09-1.92], P=0.01$, power $=60 \%$ ).

Finally, 1336 subjects were divided into two groups according to presence or absence of MS; 489 did not have

Table 3 Clinical and biochemical characteristics of the Kazakh study cohorts matched for age

\begin{tabular}{|c|c|c|c|}
\hline & Control subjects & Type 2 diabetic subjects & $P$-value \\
\hline $\bar{N}$ & 141 & 223 & \\
\hline Male,\% (n) & $41,1 \%(58)$ & $46,6 \%(104)$ & 0.39 \\
\hline Age, years & $52(43-61)$ & $53(40-63)$ & 0.11 \\
\hline Weight, kg & $72(47-125)$ & $82(46-135)$ & $<10^{-5}$ \\
\hline Height, cm & $165(140-192)$ & $166(148-188)$ & 0.31 \\
\hline $\mathrm{BMI}, \mathrm{kg} / \mathrm{m}^{2}$ & $26.56(17.2-43.1)$ & $29.74(18.4-47.2)$ & $<10^{-5}$ \\
\hline Systolic blood pressure, mm Hg & $120(90-140)$ & $130.0(100-220)$ & $<10^{-5}$ \\
\hline Diastolic blood pressure, $\mathrm{mm} \mathrm{Hg}$ & $80(60-90)$ & $80(60-130)$ & $<10^{-5}$ \\
\hline Waist circumference, cm & $89(60-180)$ & $94(60-160)$ & 0.01 \\
\hline Hip circumference, $\mathrm{cm}$ & - & $100(63-165)$ & - \\
\hline Waist/hip ratio & - & $0.95(0.54-1.83)$ & - \\
\hline Glucose, $\mathrm{mmol} / \mathrm{L}$ & $5.15(3.8-6.5)$ & $9.2(4.1-30.5)$ & $<10^{-5}$ \\
\hline Cholesterol, mmol/L & $4.9(2.4-11.8)$ & $5.2(2.8-16.7)$ & 0.12 \\
\hline Triglycerides, $\mathrm{mmol} / \mathrm{L}$ & $1.2(0.4-3.8)$ & $1.9(0.2-17.6)$ & $<10^{-5}$ \\
\hline Low-density lipoproteins, mmol/L & $4.57(1.78-15.50)$ & $4.71(1.56-8.67)$ & 0.47 \\
\hline High-density lipoproteins, mmol/L & $1.32(0.7-2.8)$ & $1.23(0.62-3.6)$ & 0.009 \\
\hline $\mathrm{HbA1c}, \%$ & $5.9(4.5-6.7)$ & $7.65(4.4-16.4)$ & $<10^{-5}$ \\
\hline Insulin, $\mu \mid \mathrm{U} / \mathrm{mL}$ & - & $12.70(0.02-97.0)$ & - \\
\hline C-peptide, ng/mL & - & $4.20(0.14-12.0)$ & - \\
\hline
\end{tabular}

Data are expressed as median (range) unless otherwise specified 
Table 4 Association of candidate SNP loci with type 2 diabetes in the age-matched Kazakh study cohorts

\begin{tabular}{|c|c|c|c|c|c|c|}
\hline \multirow[t]{2}{*}{ SNP } & \multirow[t]{2}{*}{ Gene } & \multirow[t]{2}{*}{ Major/ Minor allele } & \multicolumn{2}{|c|}{ Minor allele frequency } & \multirow{2}{*}{$\begin{array}{l}\text { Odds ratio } \\
(95 \% \mathrm{Cl})\end{array}$} & \multirow[t]{2}{*}{$P$-value } \\
\hline & & & Control $(n=141)$ & T2DM $(n=223)$ & & \\
\hline rs3751812 & FTO & $\mathrm{G} / \mathrm{T}$ & 0.24 & 0.29 & $1.41(0.97-2.07)$ & 0.07 \\
\hline rs8050136 & FTO & $\mathrm{C} / \mathrm{A}$ & 0.25 & 0.3 & $1.37(0.94-2.01)$ & 0.09 \\
\hline rs9939609 & FTO & T/A & 0.23 & 0.29 & $1.52(1.03-2.26)$ & 0.04 \\
\hline rs10811661 & $C D K N 2 A / B$ & $\mathrm{~T} / \mathrm{C}$ & 0.23 & 0.24 & $1.03(0.71-1.50)$ & 0.86 \\
\hline rs2383208 & $C D K N 2 A / B$ & $\mathrm{~A} / \mathrm{G}$ & 0.22 & 0.22 & $0.99(0.67-1.48)$ & 0.96 \\
\hline rs1111875 & HHEX & $\mathrm{T} / \mathrm{C}$ & 0.38 & 0.42 & $1.19(0.87-1.64)$ & 0.26 \\
\hline rs13266634 & SLC30A8 & $C / T$ & 0.4 & 0.32 & $0.68(0.49-0.93)$ & 0.02 \\
\hline rs4506565 & TCF7L2 & $\mathrm{A} / \mathrm{T}$ & 0.16 & 0.19 & $1.22(0.82-1.84)$ & 0.34 \\
\hline rs5215 & KCNJ11 & $\mathrm{T} / \mathrm{C}$ & 0.33 & 0.36 & $1.15(0.83-1.59)$ & 0.4 \\
\hline rs7756992 & CDKAL1 & $A / G$ & 0.31 & 0.33 & $1.11(0.79-1.56)$ & 0.55 \\
\hline rs4712523 & CDKAL1 & $A / G$ & 0.3 & 0.34 & $1.18(0.85-1.65)$ & 0.31 \\
\hline rs9465871 & CDKAL1 & $\mathrm{T} / \mathrm{C}$ & 0.29 & 0.31 & $1.07(0.76-1.51)$ & 0.67 \\
\hline rs7961581 & near TSPAN8/LGR5 & $\mathrm{T} / \mathrm{C}$ & 0.21 & 0.29 & $1.54(1.05-2.27)$ & 0.03 \\
\hline rs864745 & JAZF1 & $\mathrm{T} / \mathrm{C}$ & 0.38 & 0.39 & $1.04(0.77-1.43)$ & 0.76 \\
\hline rs12779790 & near CDC123/CAMK1D & $A / G$ & 0.18 & 0.16 & $0.89(0.55-1.44)$ & 0.64 \\
\hline rs10490072 & $B C L 11 A$ & $\mathrm{~T} / \mathrm{C}$ & 0.12 & 0.12 & $0.96(0.57-1.61)$ & 0.88 \\
\hline rs10923931 & NOTCH2 & $\mathrm{G} / \mathrm{T}$ & 0.05 & 0.07 & $1.56(0.77-3.34)$ & 0.22 \\
\hline rs7578597 & THADA & T/C & 0.06 & 0.05 & $0.91(0.46-1.80)$ & 0.78 \\
\hline rs2025804 & LEPR & $A / G$ & 0.67 & 0.6 & $0.76(0.55-1.06)$ & 0.12 \\
\hline rs2641348 & ADAM30 & $A / G$ & 0.04 & 0.07 & $1.85(0.90-4.14)$ & 0.11 \\
\hline rs9472138 & near VEGFA & $C / T$ & 0.19 & 0.2 & $1.05(0.71-1.58)$ & 0.79 \\
\hline rs1042714 & $A D R B 2$ & $\mathrm{C} / \mathrm{G}$ & 0.31 & 0.3 & $0.97(0.68-1.37)$ & 0.87 \\
\hline rs4994 & ADRB3 & $A / G$ & 0.16 & 0.19 & $1.16(0.76-1.78)$ & 0.48 \\
\hline rs1799883 & $F A B P 2$ & $C / T$ & 0.3 & 0.39 & $1.51(1.06-2.13)$ & 0.02 \\
\hline rs1801282 & PPARG & $C / G$ & 0.11 & 0.13 & $1.23(0.78-2.00)$ & 0.37 \\
\hline rs8192678 & PPARGC1A & $C / T$ & 0.36 & 0.32 & $0.82(0.59-1.15)$ & 0.26 \\
\hline rs780094 & GCKR & $C / T$ & 0.4 & 0.38 & $0.9(0.58-1.39)$ & 0.63 \\
\hline rs7944584 & $M A D D$ & $\mathrm{~A} / \mathrm{T}$ & 0.11 & 0.15 & $1.46(0.77-2.98)$ & 0.26 \\
\hline
\end{tabular}

All SNPs are analyzed in additive model. Logistic regression models were used adjusted for age and sex. Bold and italic $P$-values are statistically significant with $P<0.05$

T2DM and MS (control group) and 208 had at least three components of the MS (patients). The risk of developing at least three components of MS was associated with FTO polymorphisms (rs3751812: OR $=1.49$, CI [1.04-2.14], $P=0.03$, power $=61 \%$; rs8050136: $\mathrm{OR}=1.52$, CI [1.06-2.19], $P=0.02$, power $=65 \%$; rs9939609: $\mathrm{OR}=1.59$, CI $[1.10-2.32], P=0.01$, power $=72 \%)$ and FABP2 polymorphism (rs1799883: OR $=1.65$, CI $[1.16-$ $2.38], P=0.006$, power $=82 \%$; Additional file 9 ).

\section{Comparison of allele frequencies in Kazakh population with population data from the HapMap database}

We also comparatively analysed the differences in allele frequencies between the Kazakh population and populations of different ethnic origins (listed as follows) represented in the HapMap database: Africans (Yoruba in Ibadan, Nigeria; Luhya in Webuye, Kenya); Americans of African ancestry (South West USA); Maasai (Kinayawa, Kenya), Americans (Mexicans in Los Angeles, USA), Asians (Gujarati Indian from Houston, USA, Han Chinese in Beijing, China; Chinese population in Metropolitan Denver, USA; Japanese in Tokyo, Japan), and Europeans (Utah residents with Northern and Western European ancestry, USA; Toscani, Italy; Table 5).

As expected, significant differences in allele frequencies were found between Kazakhs and representatives of other ethnic groups for a large number of SNPs (Table 5). For the African American population, genotype data for only 25 of 28 studied SNPs were available. Allele frequencies of 22 of these 25 SNPs were significantly different from those 


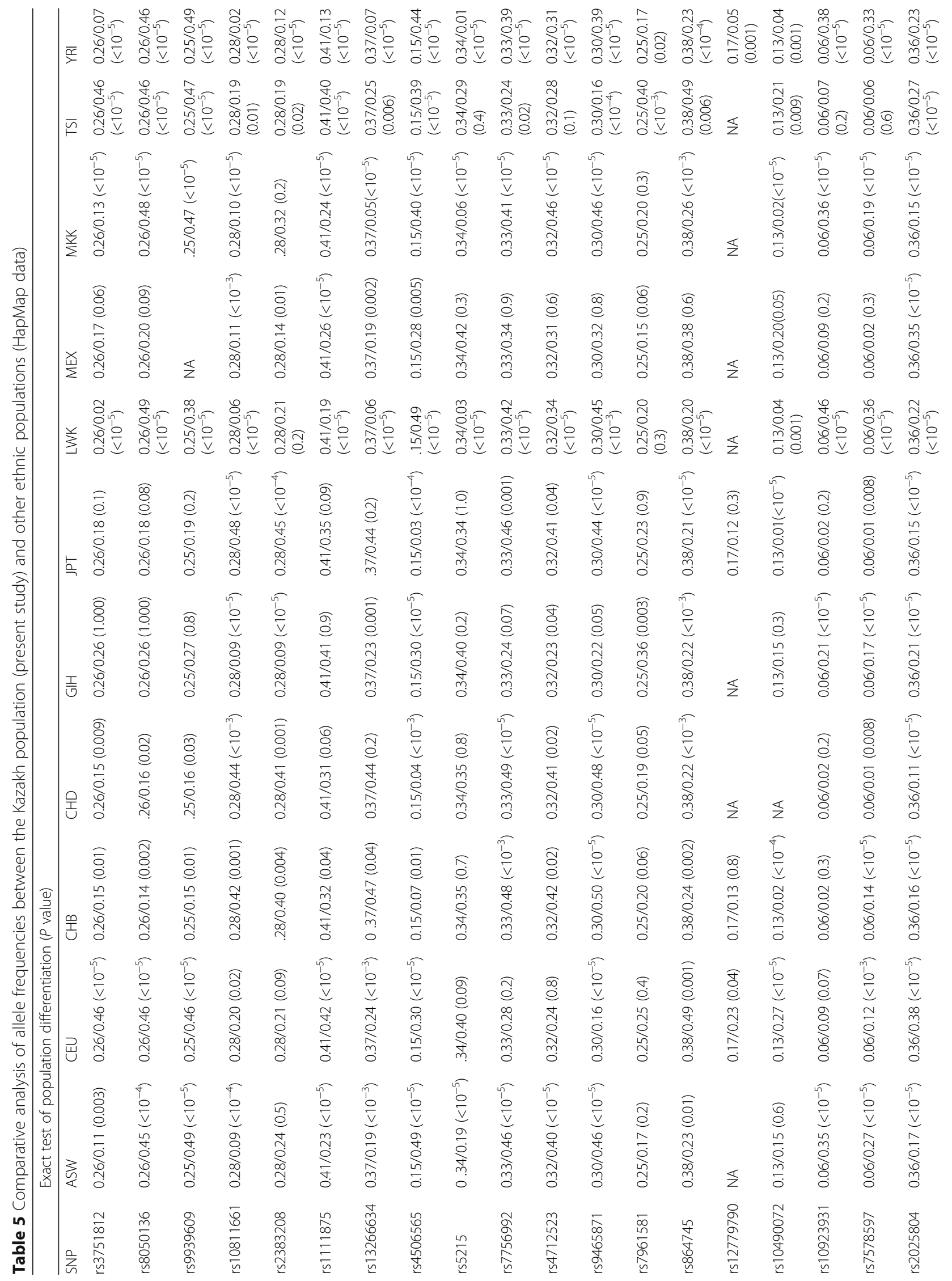




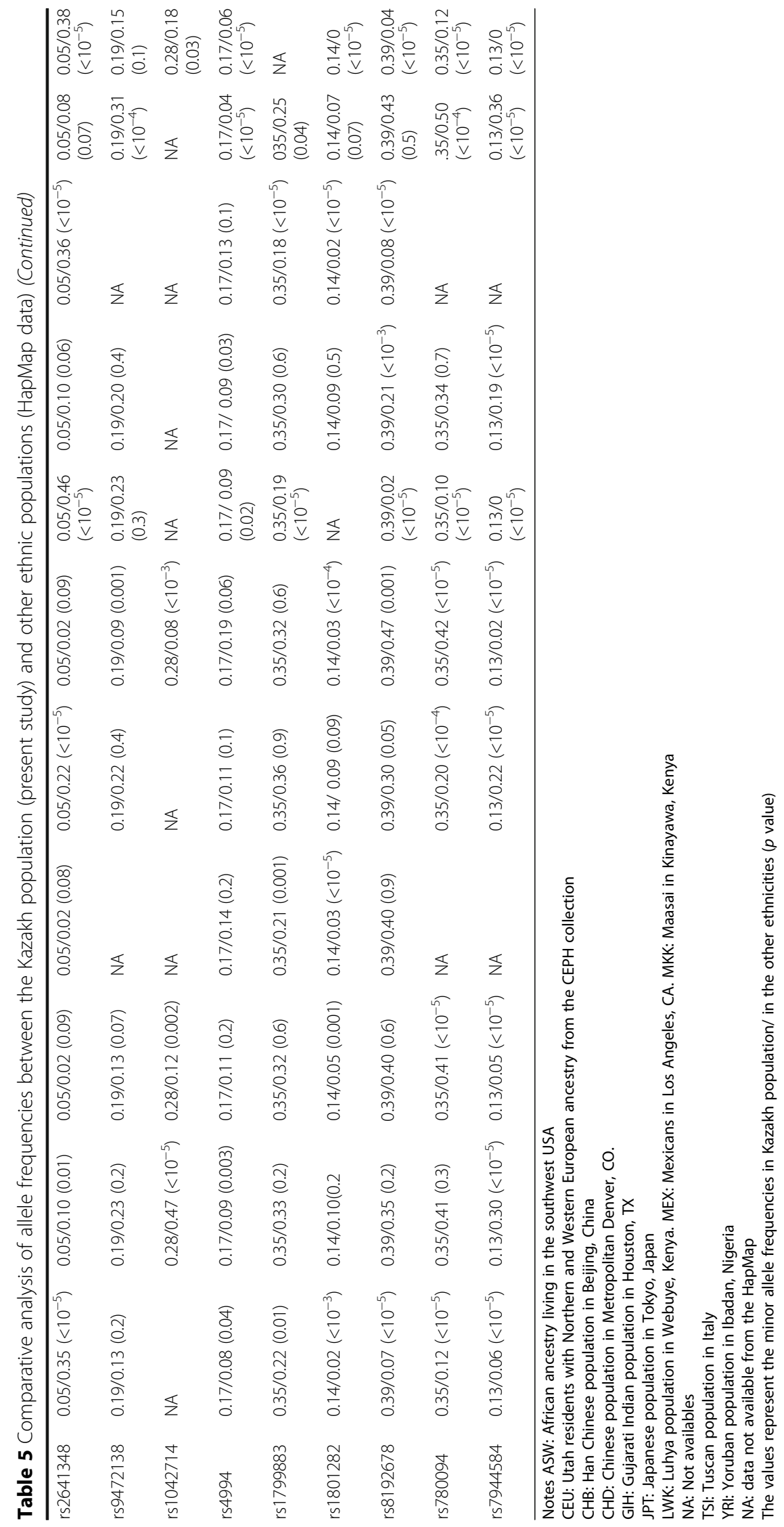


of the Kazakh population. For Caucasians, genotype data were available for 27 SNPs. Allele frequencies of 17 SNPs were significantly different between Caucasians and Kazakhs. For Asian populations, genotype data were also available for 27 of the 28 studied SNPs. Allele frequencies of 18 of these 27 SNPs were significantly different compared to those of the Kazakh population.

\section{Discussion}

In the present study, we addressed whether genetic variants previously reported $[8,12,23-43]$ to be associated with susceptibility to T2DM, obesity, and MS in other ethnic groups are also associated with obesity-related phenotypes and/or diseases in a Kazakh cohort. Kazakhs are Turkic-speaking people that live in several Central Asian countries including Kazakhstan, Uzbekistan, Kyrgyzstan, as well as in Russia, Mongolia, and China. From a historic point of view, and because of scarce genetic data, it has been suggested that the Kazakh population was formed as a result of admixture of European and Asian populations [23, 24].

To our knowledge, this is the first study showing significant associations between genetic polymorphisms within SLC30A8, TSPAN8/LGR5, FABP2, and FTO genes and susceptibility to T2DM in age-matched groups including Kazakh subjects. We also found that SNPs in $F T O$ and $F A B P 2$ are significantly associated with susceptibility to MS. Finally, SNPs in FTO were found to be significantly associated with BMI and susceptibility to obesity in the general unmatched control group.

The rs13266634 T allele in SLC30A8 was shown to have a protective effectagainstT2DM in a Kazakh age- and sexmatched cohort $(\mathrm{OR}=0.68)$. These results are in agreement with those of several large-scale studies suggesting the involvement of SLC3OA8 in the development of T2DM $[7,44,45]$. It has thus been hypothesized that the SLC30A8 gene product regulates zinc ion concentration in $\beta$-cells, as zinc has an important role in the regulation of maturation, storage, and secretion of insulin by these cells [46]. Comparative analysis of rs13266634 allelic frequencies showed significant differences between the Kazakh population and most other population groups from the HapMap database, except for Asian populations. We also observed a significant association between TSPAN8/LGR5 rs7961581 and T2DM $(\mathrm{OR}=1.54)$ in our age-matched cohort. This was in accordance with the study by Zhou et al. [47] who reported a similar association in Japanese and Chinese populations [47]. Interestingly, rs7961581 allele frequencies in the Kazakh population were not different from those in the Japanese and Chinese populations. However, in the present study, these associations were not found in the general unmatched T2DM and control cohorts.

The FABP2 gene encodes a small-bowel fatty acidlinked form of the protein, which belongs to a family of proteins that regulates lipid transport and metabolism
[46]. FABP2 rs1799883 was significantly associated with T2DM in the age-matched Kazakh cohort $(\mathrm{OR}=1.51)$ and these findings were also confirmed in the general unmatched cohort $(\mathrm{OR}=1.41)$ with a statistical power of $75 \%$ (Additional file 2). This is in agreement with previous studies showing an association between FABP2 gene polymorphisms and insulin resistance and T2DM, as well as a meta-analysis that indicated a significant association between the rs1799883 polymorphism and susceptibility to T2DM among Asian, but not Caucasian, populations [8]. In addition, we showed that rs1799883 is significantly associated with MS $(\mathrm{OR}=1.65)$, with a statistical power of $82 \%$, as well as with decreased HDL concentrations and increased SBP in control subjects; this might be important for the development of T2DM. This was also in agreement with previously reported associations between FABP2 genetic polymorphism and dyslipidaemia (high plasma concentration of TGs and low concentration of HDL) and MS in elderly subjects [47-50]. In addition, comparative analysis showed that for rs1799883 there are significant differences in allele frequencies between Kazakh and African, Asian, and Caucasian populations.

In the present study, polymorphisms in the FTO gene (rs3751812, rs8050136, andrs9939609) were found to be significantly associated with BMI, obesity, MS, LDL, and cholesterol levels in the general control Kazakh cohort. These results are consistent with those of previous studies suggesting the involvement of this gene in lipid metabolism [51, 52], obesity, T2DM [51-54], and MS in different populations [55-57]. Our sample size $(n=838)$ had power values of $72 \%, 74 \%$, and $60 \%$ to detect associations between obesity status and $\mathrm{rs} 3751812(\mathrm{OR}=1.51)$, rs8050136 $(\mathrm{OR}=1.52)$, and rs9939609 $(\mathrm{OR}=1.44)$, respectively. Furthermore, sample size $(n=697)$ allowed for the detection of associations between rs3751812 (OR = 1.49), rs8050136 (OR = 1.52), and rs9939609 $(\mathrm{OR}=1.59)$ and MS with power values of $61 \%, 65 \%$, and $72 \%$, respectively.

FTO polymorphisms were also significantly associated with T2DM in the age-matched T2DM and control cohorts (Table 4), as well as in the general T2DM and control cohorts (power > 90\%; Additional file 2). It has been suggested for many years that FTO might play an important role in controlling energy expenditure and might also be involved in energy homeostasis. However, the exact function of the FTO gene and the molecular mechanisms linking these non-coding variants with obesity remain unknown. Interestingly, although the IRX3 gene is located half a million base pairs away from the FTO gene locus, it has been recently shown that regions of the FTO gene that are associated with obesity physically interact with an $I R X 3$ gene promoter; therefore, it is possible that the IRX3 gene is also linked to obesity [58]. 
In the present study, genetic polymorphisms in CDKN2A/B, HHEX, TCF7L2, KCNJ11, CDKAL1, JAZF1, CDC123/CAMK1D, BCL11A, NOTCH2, THADA, LEPR, ADAM30, VEGFA, ADRB2, ADRB3, PPARG, PPARGC1A, $G C K R$, and $M A D D$ genes were not significantly associated with T2DM risk, MS, obesity, or with quantitative metabolic traits (TGs, cholesterol, LDL, HDL), blood pressure, or BMI. Although many studies have demonstrated significant associations between variants of these genes and some T2DM and/or obesity-related phenotypes $[8,12,26,27,29,33,34,35-38]$,other reports have failed to identify such associations [42, 59]. Negative findings in our Kazakh cohort might be potentially explained by different allele frequencies in different ethnic groups and/or the fact that the same polymorphism might have a different impact on disease susceptibility in different populations consisting of different ethnicities, and/or insufficient power of the present study to detect such differences.

\section{Conclusion}

In conclusion, we confirmed previously demonstrated associations between polymorphisms in SLC30A8, TSPAN8/ LGR5, FABP2, and FTO and T2DM in a Kazakh cohort. Interestingly, polymorphisms in FTO were significantly associated with susceptibility to MS and obesity, higher BMI, lower HDL concentrations, and higher SBP in our control group. To our knowledge, this is the first association study assessing how gene variants affect predisposition to metabolic diseases in a Kazakh cohort. The positive results as well as negative findings of the present study should be confirmed in larger cohorts of Kazakh subjects.

Some limitations of this study should be acknowledged. The case-control design is subject to selection biases and only allows for the examination of associations between genetic polymorphisms and various phenotypes, whereas causative effect cannot be demonstrated. In addition, only a limited number of SNPs (28) could be analysed in our cohort and only subsets of the entire T2DM and control cohorts could be matched for age and gender. Results with statistical power of less than $80 \%$ should therefore be taken with caution [10, 20]. Thus, a larger sample size, in particular for agematched patients and controls, would be required to assess whether the lack of association demonstrated in the present study is due to real biological differences attributed to a particular ethnic background or due to lack of statistical power. Another possible limitation of our study might be the fact that no Bonferroni correction was applied to avoid type 1 error due to multiple comparisons. If Bonferroni's correction was applied to $P$-values obtained in our study, the thresholds of significance for each comparison would be 0.0018 for 28 comparisons.
After the correction, only the rs9939609 polymorphism would be associated with type 2 diabetes in our Kazakh cohort. However, although there is the chance of type 1 error due to multiple comparisons, we believe that this correction might be too conservative as the chosen polymorphisms have already been associated with metabolic features in many studies, and because they were tested for replication in the present study.

\section{Additional files}

Additional file 1: Allele frequency and genotype distribution in the general Kazakh cohorts. (DOCX $50 \mathrm{~kb}$ )

Additional file 2: Association of candidate SNP loci with type 2 diabetes in the general Kazakh study cohorts. (DOCX $15 \mathrm{~kb}$ )

Additional file 3: Association of selected SNP with BMI in the general control Kazakh cohort. (DOCX $12 \mathrm{~kb}$ )

Additional file 4: Association of selected SNP with systolic blood pressure in the general control Kazakh cohort. (DOCX 13 kb)

Additional file 5: Association of selected SNP with high-density lipoprotein in the general control Kazakh cohort. (DOCX $13 \mathrm{~kb}$ )

Additional file 6: Association of selected SNP with low-density lipoprotein in the general control Kazakh cohort. (DOCX 13 kb)

Additional file 7: Association of selected SNP with cholesterol in the general control Kazakh cohort. (DOCX 12 kb)

Additional file 8: Association of candidate SNP with obesity in the general control Kazakh cohort. (DOCX $15 \mathrm{~kb}$ )

Additional file 9: Risk of developing at least three components of the metabolic syndrome in the general unmatched Kazakh cohort. (DOCX 15 kb)

\section{Abbreviations}

BMI: body mass index; Cl: confidence interval; DBP: diastolic blood pressure; GWAS: genome wide association studies; HC: hip circumference; HDL: highdensity lipoproteins; HWE: Hardy-Weinberg equilibrium; LDL: low-density lipoproteins; MS: metabolic syndrome; OR: odds ratio; SBP: systolic blood pressure; SNP: single nucleotide polymorphism; T2DM: type 2 diabetes mellitus; TGs: triglycerides; WC: waist circumference; WHO: World Health Organization

\section{Acknowledgements}

The authors thank the people of Almaty for their participation in this study, the Asfendiyarov Kazakh National Medical University and the many colleagues who assisted in the collection of these data.

\section{Funding}

This work was supported by grants (nO.0659, n0898GF4) from the Ministry of Education and Science of the Republic of Kazakhstan.

\section{Availability of data and materials}

Due to the presence of potentially identifying patient information, all relevant data are available to qualified researchers upon request to the corresponding author Nurgul Sikhayeva (ksnurgul@gmail.com).

\section{Authors' contributions}

Conceived and designed the experiments: NS, EZ, ER. Performed the experiments: NS, Al. Analysed the data: NSM, NS, CBE. Contributed reagents/materials/analysis tools: EZ, ER. Wrote the paper: NS, NSM, CBE. Provided critical revisions: EZ, CBE, ER. Interpreted the results: NS, Al, EZ, NSM, CBE, ER. All authors read and approved the final manuscript. 


\section{Ethics approval and consent to participate}

Study approval was obtained from the Ethics Committee of the National Centre for Biotechnology, Astana, Kazakhstan (No. 10.14.03.2012). Detailed written informed consent was obtained from all participants.

\section{Consent for publication}

Consents for publication of anthropometrical, biochemical and genetic data were obtained from all subjects involved in this study.

\section{Competing interests}

The authors declare that they have no competing interests.

\section{Publisher's Note}

Springer Nature remains neutral with regard to jurisdictional claims in published maps and institutional affiliations.

\section{Author details}

${ }^{1}$ National Center for Biotechnology, 13/5 Korgalzhyn str, Astana 010000, Kazakhstan. ${ }^{2}$ L.N. Gumilyov Eurasian National University, Astana, Kazakhstan. ${ }^{3}$ Unit of Pharmacogenetics and Clinical Psychopharmacology, Centre for Psychiatric Neuroscience, Department of Psychiatry, Lausanne University Hospital, 1008 Prilly-Lausanne, Switzerland. ${ }^{4}$ School of Pharmaceutical Sciences, University of Geneva, University of Lausanne, Geneva, Switzerland. ${ }^{5}$ School of Science and Technology, Nazarbayev University, Astana, Kazakhstan.

Received: 10 April 2017 Accepted: 13 July 2017

Published online: 24 July 2017

\section{References}

1. Wang X, Strizich G, Hu Y, Wang T, Kaplan R, Qi Q. Genetic markers of type 2 diabetes: progress in genome-wide association studies and clinical application for risk prediction. J Diabetes. 2016;8(1):24-35.

2. Lee C, Colagiuri R, Magliano D, Cameron A, Shaw J, Zimmet P, Colagiuri S. The cost of diabetes in adults in Australia. Diabetes Res Clinical Pract. 2013;99:385-90

3. Wild S, Green A, Sicree R, King H. Global prevalence of diabetes: estimates for the year 2000 and projections for 2030. Diabetes Care. 2004;27:1047-53.

4. Diabetic Association of the Republic of Kazakhstan. 2014. Available at: http://www.dark-diabet.kz/. Accessed 10 July 2014

5. DeFronzo R. From the triumvirate to the ominous octet: a new paradigm for the treatment of type 2 diabetes mellitus. Diabetes. 2009;58:773-95.

6. Sanghera D, Blackett P. Type 2 diabetes genetics: beyond GWAS. J Diabetes Metab. 2012:3:6948.

7. Omori S, Takahashi A, Hirose H, Kashiwagi A, Kaku K, Kawamori R, Nakamura Y, Maeda S. Association of CDKAL1, IGF2BP2, CDKN2A/B, HHEX, SLC30A8, and KCNJ11 with susceptibility to type 2 diabetes in a Japanese population. Diabetes. 2008:57:791-5

8. Qiu C, Ye X, Yu X, Peng X, Li T. Association between FABP2 Ala54Thr polymorphisms and type 2 diabetes mellitus risk: a HuGE review and meta-analysis. J Cell Mol Med. 2014;18:2530-5.

9. Wu H, Liu N, Yang Z, Tao X, Du Y, Wang X, Lu B, Zhang Z, Hu R, Wen J. IGF2BP2 and obesity interaction analysis for type 2 diabetes mellitus in Chinese Han population. Eur J Med Res. 2014;19:19-40.

10. Lasram K, Ben Halim N, Benrahma H, Mediene-Benchekor S, Arfa I, Hsouna S, Kefi R, Jamoussi H, Ben Ammar S, Bahri S, Abid A, Benhamamouch S, Barakat A, Abdelhak S. Contribution of CDKAL1 rs7756992 and IGF2BP2 rs4402960 polymorphisms in type 2 diabetes, diabetic complications, obesity risk and hypertension in the Tunisian population. J Diabetes. 2015;7:102-13.

11. Scott R, Lagou V, Welch R, Wheeler E, Montasser M, Luan J, Magi R, Strawbridge R, Rehnberg E, Gustafsson S, Kanoni S, Rasmussen-Torvik L, Yengo L, Lecoeur C, Shungin D, Sanna S, Sidore C, Johnson P, Jukema J, Johnson T, Mahajan A, Verweij N, Thorleifsson G, Hottenga J, Shah S, Smith A, Sennblad B, Gieger C, Salo P, Perola M, Timpson N, Evans D, Pourcain B, Wu Y, Andrews J, Hui J, Bielak L, Zhao W, Horikoshi M, Navarro P, Isaacs A, O'Connell J, Stirrups K, Vitart V, Hayward C, Esko T, Mihailov E, Fraser R, Fall T, Voight B, Raychaudhuri S, Chen H, Lindgren C, Morris A, Rayner N, Robertson N, Rybin D, Liu C, Beckmann J, Willems S, Chines P, Jackson A, Kang H, Stringham H, Song K, Tanaka T, Peden J, Goel A, Hicks A, An P, Müller-Nurasyid M, Franco-Cereceda A, Folkersen L, Marullo L, Jansen H, Oldehinkel A, Bruinenberg M, Pankow J,
North K, Forouhi N, Loos R, Edkins S, Varga T, Hallmans G, Oksa H, Antonella M, Nagaraja R, Trompet S, Ford I, Bakker S, Kong A, Kumari M, Gigante B, Herder C, Munroe P, Caulfield M, Antti J, Mangino M, Small K, Miljkovic I, Liu Y, Atalay M, Kiess W, James A, Rivadeneira F, Uitterlinden A, Palmer C, Doney A, Willemsen G, Smit J, Campbell S, Polasek O, Bonnycastle L, Hercberg S, Dimitriou M, Bolton J, Fowkes G, Kovacs P, Lindström J, Zemunik T, Bandinelli S, Wild S, Basart H, Rathmann W, Grallert H, DIAbetes Genetics Replication and Metaanalysis (DIAGRAM) Consortium, Maerz W, Kleber M, Boehm B, Peters A, Pramstaller P, Province M, Borecki I, Hastie N, Rudan I, Campbell H, Watkins H, Farrall M, Stumvoll M, Ferrucci L, Waterworth D, Bergman R, Collins F, Tuomilehto J, Watanabe R, de Geus E, Penninx B, Hofman A, Oostra B, Psaty B, Vollenweider P, Wilson J, Wright A, Hovingh G, Metspalu A, Uusitupa M, Magnusson P, Kyvik K, Kaprio J, Price J, Dedoussis G, Deloukas P, Meneton P, Lind L, Boehnke M, Shuldiner A, van Duijn C, Morris A, Toenjes A, Peyser P, Beilby J, Körner A, Kuusisto J, Laakso M, Bornstein S, Schwarz P, Lakka T, Rauramaa R, Adair L, Smith G, Spector T, Illig T, de Faire U, Hamsten A, Gudnason V, Kivimaki M, Hingorani A, Keinanen-Kiukaanniemi S, Saaristo T, Boomsma D, Stefansson K, van der Harst P, Dupuis J, Pedersen N, Sattar N, Harris T, Cucca F, Ripatti S, Salomaa V, Mohlke K, Balkau B, Froguel P, Pouta A, Jarvelin M, Wareham N, Bouatia-Naji N, McCarthy M, Franks P, Meigs J, Teslovich T, Florez J, Langenberg C, Ingelsson E, Prokopenko I, Barroso I. Largescale association analyses identify new loci influencing glycemic traits and provide insight into the underlying biological pathways. Nat Genet. 2012;44: 991-1005.

12. Zeggini $E$, Scott $L$, Saxena R, Voight B, Marchini J, Hu T, de Bakker $P$, Abecasis G, Almgren P, Andersen G, Ardlie K, Boström K, Bergman R, Bonnycastle L, Borch-Johnsen K, Burtt N, Chen H, Chines P, Daly M, Deodhar P, Ding C, Doney A, Duren W, Elliott K, Erdos M, Frayling T, Freathy $R$, Gianniny L, Grallert H, Grarup N, Groves C, Guiducci C, Hansen T, Herder C, Hitman G, Hughes T, Isomaa B, Jackson A, Jørgensen T, Kong A, Kubalanza K, Kuruvilla F, Kuusisto J, Langenberg C, Lango H, Lauritzen T, Li Y, Lindgren C, Lyssenko V, Marvelle A, Meisinger C, Midthjell K, Mohlke K, Morken M, Morris A, Narisu N, Nilsson P, Owen K, Palmer C, Payne F, Perry J, Pettersen E, Platou C, Prokopenko I, Qi L, Qin L, Rayner N, Rees M, Roix J, Sandbaek A, Shields B, Sjögren M, Steinthorsdottir V, Stringham H, Swift A, Thorleifsson G, Thorsteinsdottir U, Timpson N, Tuomi T, Tuomilehto J, Walker M, Watanabe R, Weedon M, Willer C, Wellcome Trust Case Control Consortium, Illig T, Hveem K, Hu F, Laakso M, Stefansson K, Pedersen O, Wareham N, Barroso I, Hattersley A, Collins F, Groop L, McCarthy M, Boehnke M, Altshuler D. Meta-analysis of genome-wide association data and large-scale replication identifies additional susceptibility loci for type 2 diabetes. Nat Genet. 2008;40:638-45.

13. World Health Organization. Definition, diagnosis and classification of diabetes mellitus and its complications: report of a WHO consultation. Part 1: diagnosis and classification of diabetes mellitus. Geneva: World Health Org; 1999.

14. World Health Organization. Definition and diagnosis of diabetes mellitus and intermediate hyperglycemia: report of a WHO/IDF consultation. Geneva: World Health Org; 2006.

15. Expert Panel on Detection, Evaluation, and Treatment of High Blood Cholesterol in Adults. Executive summary of the third report of the National Cholesterol Education Program (NCEP) Expert Panel on Detection, Evaluation, and Treatment of High Blood Cholesterol in Adults (Adult Treatment Panel III). JAMA. 2001;285:2486-97.

16. Miller S, Dykes D, Polesky H. A simple salting out procedure for extracting DNA from human nucleated cells. Nucleic Acids Res. 1988;16:1215.

17. Stowell S. Instant R: an introduction to R for statistical analysis: Jotunheim Publishing; 2012.

18. The Comprehensive R Archive Network. 2014. Available at: http://cran.rproject.org/other-docs.html. Accessed 20 July 2014.

19. Excoffier L, Laval G, Schneider S. Arlequin ver. 3.0: an integrated software package. Evol Bioinform Online. 2005;1:47-50.

20. Dupont W, Plummer W. Power and sample size calculations. A review and computer program. Control Clin Trials. 1990;11:116-28.

21. Thorisson G, Smith A, Krishnan L, Stein L. The international HapMap project web site. Genome Res. 2005;15:1591-3.

22. Raymond M, Rousset F. An exact test for population differentiation. Evol Bioinformatics Online. 1995;49:1280-3.

23. Comas D, Calafell F, Mateu E, Pérez-Lezaun A, Bosch E, Martínez-Arias R, Clarimon J, Facchini F, Fiori G, Luiselli D, Pettener D, Bertranpetit J. Trading genes along the silk road: mtDNA sequences and the origin of central Asian populations. Am J Hum Genet. 1998;63:1824-38. 
24. Lalueza-Fox C, Sampietro M, Gilbert M, Castri L, Facchini F, Pettener D, Bertranpetit J. Unravelling migrations in the steppe: mitochondrial DNA sequences from ancient central Asians. Proc Biol Sci. 2004;271:941-7.

25. Alharbi K, Richardson T, Imran Ali K, Rabbani R, Abdul Khader M, Christopher B, Tom G, Waleed T, Al-Daghri N, Day I. Influence of adiposity-related genetic markers in a population of Saudi Arabians where other variables influencing obesity may be reduced. Disease Marker. 2014; http://dx.doi.org/10.1155/2014/758232

26. Liu Y, Liu Z, Song Y, Zhou D, Zhang D, Zhao T, Chen Z, Yu L, Yang Y, Feng G, Li J, Zhang J, Liu S, Zhang Z, He L, Xu H. Meta-analysis added power to identify variants in FTO associated with type 2 diabetes and obesity in the Asian population. Obesity (Silver Spring). 2010;18:1619-24.

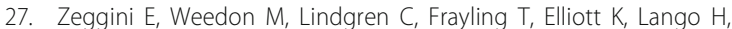
Timpson N, Perry J, Rayner N, Freathy R, Barrett J, Shields B, Morris A, Ellard S, Groves C, Harries L, Marchini J, Owen K, Knight B, Cardon L, Walker M, Hitman G, Morris A, Doney A, Wellcome Trust case control consortium (WTCCC), McCarthy M, Hattersley A. Replication of genomewide association signals in UK samples reveals risk loci for type 2 diabetes. Science. 2007;316:1336-41.

28. Takeuchi F, Serizawa M, Yamamoto K, Fujisawa T, Nakashima E, Ohnaka K, Ikegami H, Sugiyama T, Katsuya T, Miyagishi M, Nakashima N, Nawata H, Nakamura J, Kono S, Takayanagi R, Kato N. Confirmation of multiple risk loci and genetic impacts by a genome-wide association study of type 2 diabetes in the Japanese population. Diabetes. 2009;58:1690-9.

29. Rung J, Cauchi S, Albrechtsen A, Shen L, Rocheleau G, Cavalcanti-Proença C, Bacot F, Balkau B, Belisle A, Borch-Johnsen K, Charpentier G, Dina C, Durand E, Elliott P, Hadjadj S, Jarvelin M, Laitinen J, Lauritzen T, Marre M, Mazur A, Meyre D, Montpetit A, Pisinger C, Posner B, Poulsen P, Pouta A, Prentki M, Ribel-Madsen R, Ruokonen A, Sandbaek A, Serre D, Tichet J, Vaxillaire M, Wojtaszewski J, Vaag A, Hansen T, Polychronakos C, Pedersen O, Froguel P, Sladek R. Genetic variant near IRS1 is associated with type 2 diabetes, insulin resistance and hyperinsulinemia. Nat Genet. 2009:41:1110-5.

30. Wellcome Trust Case Control Consortium. Genome-wide association study of 14,000 cases of seven common diseases and 3,000 shared controls. Nature. 2007;447:661-78.

31. Timpson N, Lindgren C, Weedon M, Randall J, Ouwehand W, Strachan D, Rayner N, Walker M, Hitman G, Doney A, Palmer C, Morris A, Hattersley A, Zeggini $\mathrm{E}$, Frayling T, McCarthy M. Adiposity-related heterogeneity in patterns of type 2 diabetes susceptibility observed in genome-wideassociation data. Diabetes. 2009;58:505-10.

32. Steinthorsdottir $V$, Thorleifsson $G$, Reynisdottir I, Benediktsson R, Jonsdottir $T$, Walters G, Styrkarsdottir U, Gretarsdottir S, Emilsson V, Ghosh S, Baker A, Snorradottir S, Bjarnason H, Ng M, Hansen T, Bagger Y, Wilensky R, Reilly M, Adeyemo A, Chen Y, Zhou J, Gudnason V, Chen G, Huang H, Lashley K, Doumatey A, So W, Ma R, Andersen G, Borch-Johnsen K, Jorgensen T, van Vliet-Ostaptchouk J, Hofker M, Wijmenga C, Christiansen C, Rader D, Rotimi C, Gurney M, Chan J, Pedersen O, Sigurdsson G, Gulcher J, Thorsteinsdottir U, Kong A, Stefansson K. A variant in CDKAL1 influences insulin response and risk of type 2 diabetes. Nat Genet. 2007;39:770-5.

33. Traurig M, Perez J, Ma L, Bian L, Kobes S, Hanson R, Knowler W, Krakoff J, Bogardus C, Baier L. Variants in the LEPR gene are nominally associated with higher BMI and lower 24-h energy expenditure in pima Indians. Obesity (Silver Spring). 2012;20:2426-30.

34. Pinelli M, Giacchetti M, Acquaviva F, Cocozza S, Donnarumma G, Lapice E, Riccardi G, Romano G, Vaccaro O, Monticelli A. Beta2-adrenergic receptor and UCP3 variants modulate the relationship between age and type 2 diabetes mellitus. BMC Med Genet. 2006;7:85.

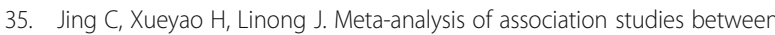
five candidate genes and type 2 diabetes in Chinese Han population. Endocrine. 2012:42:307-20.

36. Scott L, Mohlke K, Bonnycastle L, Willer C, Li Y, Duren W, Erdos M Stringham $H$, Chines $P$, Jackson A, Prokunina-Olsson L, Ding C, Swift A Narisu N, Hu T, Pruim R, Xiao R, Li X, Conneely K, Riebow N, Sprau A, Tong M, White P, Hetrick K, Barnhart M, Bark C, Goldstein J, Watkins L, Xiang F, Saramies J, Buchanan T, Watanabe R, Valle T, Kinnunen L, Abecasis G, Pugh E, Doheny K, Bergman R, Tuomilehto J, Collins F, Boehnke M. A genome-wide association study of type 2 diabetes in Finns detects multiple susceptibility variants. Science. 2007:316:1341-5.

37. Barroso I, Luan J, Sandhu M, Franks P, Crowley V, Schafer A, O'Rahilly S, Wareham N. Meta-analysis of the Gly482Ser variant in PPARGC1A in type 2 diabetes and related phenotypes. Diabetologia. 2006;49:501-5.
38. Onuma H, Tabara $Y$, Kawamoto R, Shimizu I, Kawamura R, Takata $Y$, Nishida W, Ohashi J, Miki T, Kohara K, Makino H, Osawa H. The GCKR rs780094 polymorphism is associated with susceptibility of type 2 diabetes, reduced fasting plasma glucose levels, increased triglycerides levels and lower HOMA-IR in Japanese population. J Hum Genet. 2010; 55:600-4.

39. Hu C, Zhang R, Wang C, Wang J, Ma X, Hou X, Lu J, Yu W, Jiang F, Bao Y, Xiang K, Jia W. Variants from GIPR, TCF7L2, DGKB, MADD, CRY2, GLIS3, PROX1, SLC30A8 and IGF1 are associated with glucose metabolism in the Chinese. PLoS One. 2010; doi:10.1371/journal.pone.0015542.

40. Zhang S, Xiao J, Ren Q, Han X, Tang Y, Yang W, Ji L. Replication of association study between type 2 diabetes mellitus and IGF2BP2 in Han Chinese population. Chin Med J. 2013;126:4013-8.

41. Rodriguez S, Eiriksdottir G, Gaunt T, Harris T, Launer L, Gudnason V, Day I. IGF2BP1, IGF2BP2 and IGF2BP3 genotype, haplotype and genetic model studies in metabolic syndrome traits and diabetes. Growth Hormon IGF Res. 2010;20:310-8.

42. Duesing K, Fatemifar G, Charpentier G, Marre M, Tichet J, Hercberg S, Balkau $B$, Froguel $\mathrm{P}$, Gibson F. Strong association of common variants in the CDKN2A/CDKN2B region with type 2 diabetes in French Europids. Diabetologia. 2008;51:821-6.

43. Webster R, Warrington N, Beilby J, Frayling T, Palmer L. The longitudinal association of common susceptibility variants for type 2 diabetes and obesity with fasting glucose level and BMI. BMC Med Genet. 2010;11:140.

44. Yi B, Huang G, Zhou Z. Different role of zinc transporter 8 between type 1 diabetes mellitus and type 2 diabetes mellitus. J Diabetes Investiq. 2016;7(4):459-65.

45. Staiger H, Machicao F, Stefan N, Tschritter O, Thamer C, Kantartzis K, Schafer $\mathrm{S}$, Kirchhoff $\mathrm{K}$, Fritsche A, Haring H. Polymorphisms within novel risk loci for type 2 diabetes determine $\beta$-cell function. PLoS One. 2007; doi:10.1371/ journal.pone.0000832.

46. Chimienti F, Devergnas S, Favier A, Seve M. Identification and cloning of a beta-cell-specific zinc transporter, ZnT-8, localized into insulin secretory granules. Diabetes. 2004;53:2330-7.

47. Zhou D, Liu Y, Zhang D, Liu S, Yu L, Yang Y, Zhao T, Chen Z, Kan M, Zhang Z, Feng $G, X u H$, He L. Variations in/nearby genes coding for JAZF1, TSPAN8/LGR5 and HHEX-IDE and risk of type 2 diabetes in Han Chinese. J Hum Genet. 2010;55:810-5.

48. Larifla L, Rambhojan C, Joannes M-O, Maimaitiming-Madani S, Donnet J, Marianne-Pepin T, Chout R, Roussel R, Foucan L. Gene polymorphisms of FABP2, ADIPOQ and ANP and risk of Hypertriglyceridemia and metabolic syndrome in afro-Caribbeans. PlosOne. 2016;11(9):e0163421.

49. Galluzzi J, Cupples L, Otvos J, Wilson P, Schaefer E, Ordovas J. Association of the $\mathrm{a} / \mathrm{T} 54$ polymorphism in the intestinal fatty acid binding protein with variations in plasma lipids in the Framingham offspring study. Atherosclerosis. 2001;159:417-24.

50. Turkovic L, Pizent A, Dodig S, Pavlovic M, Pasalic D. FABP2 gene polymorphism and metabolic syndrome in elderly people of Croatian descent. Biochem Med (Zagreb). 2012;22:217-24.

51. Apalasamy Y, Moy F, Rampal S, Bulgiba A, Mohamed Z. Genetic associations of the INSIG2 rs7566605 polymorphism with obesity-related metabolic traits in Malaysian Malays. Genet Mol Res. 2014;13:4904-10.

52. Teran-Garcia M, Vazquez-Vidal I, Andrade F, Mosley M, Medina-Cerda E, Aradillas-Garcia C. FTO genotype is associated with body mass index and waist circumference in Mexican young adults. OJGen. 2013;3:44-8.

53. Kawajiri T, Osaki Y, Kishimoto T. Association of gene polymorphism of the fat mass and obesity associated gene with metabolic syndrome: a retrospective cohort study in Japanese workers. Yonago Acta medica. 2012;55:29-40.

54. Rouskas K, Kouvatsi A, Paletas K, Papazoglou D, Tsapas A, Lobbens S, Vatin V, Durand E, Labrune Y, Delplanque J, Meyre D, Froguel F. Common variants in FTO, MC4R, TMEM18, PRL, AIF1, and PCSK1 show evidence of association with adult obesity in the Greek population. Obesity. 2012;20:389-95.

55. Attaoua R, Ait El Mkadem S, Lautier C, Kaouache S, Renard E, Brun J, Fedou C, Gris J, Bringer J, Grigorescu F. Association of the FTO gene with obesity and the metabolic syndrome is independent of the IRS-2 gene in the female population of southern France. Diabetes Metab. 2009:35:476-83.

56. de Luis D, Aller R, Conde R, Izaola O, de la Fuente B, Sagrado M. Relation of the rs9939609 gene variant in FTO with metabolic syndrome in obese female patients. J Diabetes Complicat. 2013;27:346-50. 
57. Chang Y, Yu Y, Chuang L. Molecular genetics of metabolic syndrome. eLS. Chichester: John Wiley \& Sons Ltd; 2013. doi:10.1002/9780470015902. a0024320.

58. Smemo S, Tena J, Kim K, Gamazon E, Sakabe N, Gómez-Marín C, Aneas I, Credidio F, Sobreira D, Wasserman N, Lee J, Puviindran V, Tam D, Shen M, Son J, Vakili N, Sung H, Naranjo S, Acemel R, Manzanares M, Nagy A, Cox N, Hui C, Gomez-Skarmeta J, Nobrega M. Obesity-associated variants within FTO form long-range functional connections with IRX3. Nature. 2014;507:371-5

59. Lara-Riegos J, Ortiz-López M, Peña-Espinoza B, Montúfar-Robles I, Peña-Rico M, Sánchez-Pozos K, Granados-Silvestre M, Menjivar M. Diabetes susceptibility in Mayas: evidence for the involvement of polymorphisms in HHEX, HNF4a, KCNJ11, PPARY, CDKN2A/2B, SLC30A8, CDC123/CAMK1D, TCF7L2, ABCA1 and SLC16A11 genes. Gene. 2015;565:68-75.

60. Frayling $T$, Timpson $N$, Weedon $M$, Zeggini $E$, Freathy $R$, Lindgren C, Perry J, Elliott K, Lango H, Rayner N, Shields B, Harries L, Barrett J, Ellard S, Groves C, Knight B, Patch A, Ness A, Ebrahim S, Lawlor D, Ring S, Ben-Shlomo Y, Jarvelin M, Sovio U, Bennett A, Melzer D, Ferruccim L, Loos R, Barroso I, Wareham N, Karpe F, Owen K, Cardon L, Walker M, Hitman G, Palmer C, Doney A, Morris A, Smith G, Hattersley A, McCarthy M. A common variant in the FTO genes is associated with body mass index and predisposes to childhood and adult obesity. Science. 2007:316:889-94.

Submit your next manuscript to BioMed Central and we will help you at every step:

- We accept pre-submission inquiries

- Our selector tool helps you to find the most relevant journal

- We provide round the clock customer support

- Convenient online submission

- Thorough peer review

- Inclusion in PubMed and all major indexing services

- Maximum visibility for your research

Submit your manuscript at www.biomedcentral.com/submit
Biomed Central 